\title{
Komunikat
}

\section{Tradycyjny a współczesny paradygmat cywilizacyjno-polityczny w Europie Środkowo-Wschodniej}

I.

Europa Środkowo-Wschodnia, podobnie zresztą jak Europa w ogóle, jest pojęciem geograficzno-polityczno-cywilizacyjnym, którego granice są umowne i płynne, co wywiera swój wpływ także na ustrojowopolityczne procesy dokonujące się na tym obszarze. Możemy założyć, że jego granice obejmują obszar znajdujący się pomiędzy zachodnią granicą byłego NRD i wschodnimi rubieżami Rzeczypospolitej Obojga Narodów oraz między Bałtykiem a Bałkanami. Są to tereny, które nie wchodziły w skład archetypicznej karolińskiej Europy romańsko-germańskiej, ale żywioł teutoński odgrywa na nich dużą rolę, jako że przez kilkaset lat uparcie realizował Drang nach Osten. Póki co nie zakończyło się jednak jakimś wyraźnym, politycznym ukoronowaniem, ponieważ w 1945 r. granica niemiecko-polska wróciła mniej więcej do wyjściowej wersji. Działo się tak, gdyż jednoczona przez Kreml Słowiańszczyzna, począwszy co najmniej od Piotra Wielkiego, rosła w siłę, co zakończyło się przegrodzeniem Starego Kontynentu Żelazną Kurtyną, przekreślającą podboje następców Karola Wielkiego. Po upadku Muru „Cywilizacja Północnoatlantycka” ponownie rozprzestrzeniła się w kierunku wyznaczonym przez „skrwawiony miecz margrabiego Hodona i świszczącą rózgę pruskiego nauczyciela we Wrześni”, osiągając granice byłego Kraju Rad, a nawet przekraczając je w Nadbałtyce. Te przeciwstaw- 
nie geograficznie zwrócone cywilizacyjno-imperialne trendy, przetaczające się przez środkowoeuropejskie równiny, uświadamiają nam, że „niespokojny obszar między Niemcami a Rosją" wyróżnia się przede wszystkim tym, że opiera się rusyfikacji, względnie germanizacji, ale nacisk Berlina oraz Moskwy jest trudny do przeoczenia, gdyż egzogeniczne siły Europy Środkowo-Wschodniej są zbyt słabe, aby móc stworzyć konkurencyjny względem dwóch wielkich sąsiadów ośrodek polityczny. Niegdyś udało się to dzięki sojuszowi panów krakowskich z Giedyminowiczami, których następcami w sporym stopniu zostali Habsburgowie, ale po rozpadzie Austro-Węgier wizja mocnej środkowoeuropejskiej konkurencji, z którą musieliby się liczyć Prusacy i Moskale, została zasadniczo pogrzebana. Co prawda, pojawiała się ona w nadwiślańskich elukubracjach międzywojennego dwudziestolecia, lecz okazały się one „mierzeniem siły na zamiary”, względnie „myśleniem życzeniowym”, brutalnie zweryfikowanym przez II wojnę światową.

W wymiarze prawnopaństwowym skutkujące słabością rozproszkowanie przejawia się w braku własnych szerszych koncepcji, którym nadawanoby oficjalną postać, która ewentualnie mogłaby się spotkać z zainteresowaniem zagranicy. Ostatnim przejawem propagowania samodzielnych rozwiązań była Konstytucja kwietniowa.

Nie przetrwała ona próby czasu, gdyż nadeszła wojna, której rezultaty potwierdziły prawidłowość polegającą na tym, że Europa Środkowo-Wschodnia ulega impulsom przychodzącym z zewnątrz, bo ma zbyt mało zasobów ideowo-materialnych, aby narzucać swoją wolę innym. To historyczne zjawisko jest dobrze widoczne w wydawanych gdzie indziej książkach, poświęconych jakimś globalnym problemom, w których nasza część Europy zajmuje marginalną pozycję. Jeśli publikacje ukazują się w jakimś zachodniosłowiańskim kraju, na Węgrzech czy w Rumunii, to wówczas może być sporo o współrodakach, ale o sąsiadach „zza miedzy biegnącej przez środkowoeuropejski grajdołek" raczej już nie. Wynika to z tego, że stosunki między ludami i państwami znajdującymi się w tej części Europy nie są szczególnie ożywione. Ich elity kulturowo-polityczne spoglądają tęsknie na zewnątrz, oczekując stamtąd ożywczych impulsów. Marzą one o zaproszeniu na jakiś egzogeniczny rydwan czy salon, gdzie w tłumie podobnych sobie satelitów będą mogły oklaskiwać wielkich tego świata. Pragną w doskonały sposób naśladować podziwianych hegemonów, przyjmując od nich w postawie po- 
kornego uwielbienia pouczenia i wyrazy zadowolenia $\mathrm{z}$ dobrze odrobionej lekcji. Przeziera przez nich wtórność, udzielająca się naśladującym ich masom, z pokorą przyjmującym okcydentalny dyktat ideowy, nakazujący przebierać państwowości w konstytucyjno-demoliberalne kostiumy.

Wyjątkiem od tej zasady był husytyzm, w którym przejawiło się pragnienie kroczenia własną, czeską drogą do chrześcijańskich ideałów. Ten ruch religijno-militarny wywarł duże wrażenie na ówczesnej międzynarodowej opinii publicznej, przygotowując ją na pojawienie się Lutra. Siła oddziaływania husyckiego przesłania była wzmacniania dzięki temu, że Praga była cesarską stolicą, co w naturalny sposób zwiększało wagę dziejących się w niej i w jej pobliżu wydarzeń. Wydaje się, że na następny przykład społeczno-ideowego fermentu, dziejącego się w Europie Środkowo-Wschodniej, mającego dość samodzielny charakter i wzbudzającego spore zainteresowanie daleko poza tym obszarem, trzeba było czekać do 1968 r., gdy Praska Wiosna rozkwitła hasłem Socjalizmu z Ludzką Twarzą, wzbudzającego nadzieje lewicy pod wszystkimi szerokościami geograficznymi. Oczekiwano, że nastąpi rozkwit szkicowanego po 1945 r. modelu demokracji ludowej, mającej syntetyzować najlepsze cechy radzieckiego i zachodniego modelu przy jednoczesnym unikaniu ich najpoważniejszych wad. Ta Trzecia Droga miała charakteryzować się „rozsądnie ograniczonym” pluralizmem politycznym i ograniczeniem uznanej za przesadną aktywności państwa w sferze gospodarczej. W moskiewskiej Centrali, jak również w stolicach sąsiednich „demoludów”, uznano jednak, że jest to niebezpieczny rewizjonizm.

Po 12 latach od rozjechania czechosłowackiego „odchylenia prawicowo-nacjonalistycznego" przez sowieckie czołgi rewizjonistyczny wirus pokazał swoje możliwości nad Bałtykiem, gdzie na bramie Stoczni Gdańskiej im. Lenina burząca się klasa robotnicza wywiesiła slogan „Socjalizm tak, wypaczenia nie!”. Przy odrobinie dobrej woli możemy uznać Solidarność za przejaw schizmy w łonie Międzynarodowego Ruchu Robotniczego, dążącej do jego ochrzczenia na złość „opium dla intelektualistów” w postaci marksizmu-leninizmu. W tej narracji rozpad ZSRR był skutkiem zwycięstwa stoczniowego socjalizmu pobożnego nad urzędowym ateistycznym komunizmem, obalonym przez gdański Wiatr od Morza, niosący na swoich skrzydłach przesłanie zapisane w dwudziestu jeden Postulatach, przybitych na Stocz- 
niowych Wrotach, które można potraktować jako Manifest Biednych i Pokrzywdzonych pomimo życia w „ustroju sprawiedliwości społecznej”.

Znacznie częściej jednak huragany nadciągające ze strony wschodzącego czy zachodzącego słońca lub z mroźnej Północy (Wikingowie, a następnie Szwedzi) względnie skwarnego Południa (Turcy), pokazywały ludom nad Wisłą, Wełtawą oraz Dunajem ich podrzędne miejsce w „globalnej tabeli rang", uświadamiając miejscowym przywódcom, że powinni przede wszystkim myśleć o przetrwaniu, niezwykle trudnym bez przyjęcia narzucanych z zewnątrz reguł. Najważniejsze z nich miały charakter religijny, czemu trudno się dziwić, zważając na to, że pogańskie plemiona nie miały szans przetrwania bez zmiany „starowierskiego” stanu. Trybalni wodzowie mogli bohatersko prowadzić swoich współplemieńców do zagłady w konfrontacji z lepiej uzbrojonymi i zorganizowanymi chrześcijanami lub przyjąć ich wiarę. Realny wybór polegał na obraniu opcji rzymskiej, względnie carogrodzkiej. Przyjmowanie jednego z tych dwóch wariantów spowodowało, że nastąpiło trwałe cywilizacyjne rozszczepienie Środkowo-Wschodniej Europy na papiesko-łacińską i schizmatycko-grecką. Początek czasów nowożytnych skomplikował jeszcze sytuację przez protestantyzację części dotychczas katolickich obszarów, choć w sporym zakresie okazała się ona krótkotrwała i powierzchowna, gdy nadszedł czas kontrreformacji. Doprowadziła ona do rekatolizacji, co prawda w niemałej mierze raczej oficjalnej niż ugruntowanej w sumieniach Czech, oraz wzmocniła nadwerężone wpływy Stolicy Apostolskiej w innych krajach monarchii habsburskiej. Dzięki temu katolicyzm pozostał najważniejszą denominacją konfesyjną Europy Środkowo-Wschodniej, co znalazło wyraziste potwierdzenie w fakcie wyboru krakowskiego biskupa Karola Wojtyły na Stolicę Piotrową, a po 1989 r. w konstytucyjnym podkreśleniu szczególnych stosunków między RP a Stolicą Apostolską.

Zróżnicowanie konfesyjne idzie w parze z pluralizmem językowo-narodowym. Na wschód od Łaby i Adygi po Pacyfik na wschodzie dominują języki słowiańskie, traktowane niejednokrotnie przez zachodnich obserwatorów jako mało zróżnicowany substrat lingwistyczny, przez co spoglądając z tamtej perspektywy, zacierają się różnice między miejscowymi etniami, jawiącymi się jako odgałęzienia szeroko rozpostartej ruszczyzny. Okoliczność ta była wykorzystywana w XIX w. przez panslawistów, pamiętających o puszkinowskim postulacie „wlania się wszystkich słowiańskich rzek w rosyjskie mo- 
rze”, jednak rozbudzone przez niemiecki romantyzm nacjonalizmy podniosły świadomość narodową „zakordonnych” Braci-Słowian do tego stopnia, że „wiejski lud wszedł do niemiecko-żydowskich miast i obudził w nich pamięć o Lechu i Czechu, nie ulegając zwodniczym pieniom potomków Rusa”. W przypadku Polaków potężną pomocą w zwycięskim przebiegu tego procesu było trwanie rycersko-szlacheckiej elity, utrzymującej nieprzerwanie świadomość własnej odrębności od mieszkowych czasów. Inaczej było w Czechach i na Morawach, bowiem po białogórskiej tragedii przestała istnieć warstwa rodzimych feudałów i „świadoma czeskość pogrążyła się w głębokim śnie”, z którego została wyrwana w XIX stuleciu przez garstkę „czecholubów”, z uporem maniaka snujących się po zalewanej przez agresywną niemczyznę prowincji i zbierających okruchy zagubionej tradycji, aby cierpliwie zlepiać z nich duchowy materiał dla nowoczesnego narodu. Tenże po skonsolidowaniu się w etnicznej postaci mógłby następnie stać się politycznym podmiotem, aspirującym do suwerenności w przykrojonej na jego miarę państwowości.

Akcja narodowego uświadomienia udała się, ponieważ czynnik „genetyczno-językowy" okazał się silniejszy od skutków trwającej wiele dekad asymilacji. Ten sam mechanizm wystąpił w Górnych Węgrzech (Felvidék), gdzie w XX stuleciu zwyciężyła jednak słowackość, doprowadzając do odłączenia się Słowacji najpierw od Węgier, a następnie od Czechosłowacji. Nie inaczej było na Litwie, strząsającej z siebie - na fali upolitycznienia chłopstwa - „wielowiekową polską okupacje”, oraz na Łotwie, gdy upowszechnienie edukacji, reforma rolna i rewolucja podkopały władzę niemieckich baronów. Dzięki tym procesom po 1918 r. można było przekształcać polityczną mapę tej części Europy w myśl zasady samostanowienia etnicznych narodów, którym przywracano rangę narodów politycznych lub po raz pierwszy nadawano im taki status.

Generalny trend w ponapoleońskich czasach przejawił się zatem w demokratyzacji, rozkładającej tradycyjne imperialne konstrukcje i przywracającej poniekąd sytuację sprzed ekspansji chrześcijaństwa, zacierającej te etniczno-plemienne odmienności, które nie wyraziły się w konstruowanych w późnej fazie średniowiecza królestwach. Niektóre z nich potrafiły przetrwać w poniekąd latentnym stanie, pozbawione wynarowodowionej warstwy kierowniczej, przez całe wieki, aby powstać do samodzielnego życia 
politycznego wówczas, gdy nad kontynentem powiały sprzyjające, ludowładcze porywy, budząc plebejskie tęsknoty do samodzielnego, gromadnego bytowania „ze swemi” na przekór „perfidnym, obcym panom, wyzyskującym bezwzględnie biednych wieśniaków, zabierającym im produkt dodatkowy i kradnącym historię". Jest ona po 1918 r. i emancypacji politycznej bardziej lub mniej historycznych narodów Europy Środkowo-Wschodniej pisana na nowo na potrzeby państwowych szkół powszechnych po to, aby podkreślać własne krzywdy, gloryfikować wynajdowanych intensywnie bojowników o niepodległość, pokazywać minioną wielkość lub tłumaczyć dlaczego źli najeźdźcy nie dopuścili do niej etc. Słowem, tworzy się mitologię narodowo-państwową, mającą zastąpić sławiące obalone cesarstwa narracje, które okazały się głęboko niesłuszne na innym etapie rozwoju, naznaczonym oficjalną wiarą w niezmożoną siłę sprawczą przekształconych w narody ludów, sięgających po swoje państwa i utrwalających zdobycze w pisanych konstytucjach, tych ,jurydycznych fetyszach zwycięskiego mieszczaństwa”.

II.

Stare mity państwowotwórcze zostały w wymiarze globalnym przekreślone w 1919 r. przez Wilsona, który w swoim burżuazyjnym kostiumie przepłynął na nowoczesnym parowcu Atlantyk po to, aby głosić Demokratyczną Dobrą Nowinę wymęczonej przez wojnę Europie. Przechodził on do porządku dziennego nad tym, że zniszczenia Wielkiej Wojny miały swoją ideologiczną przyczynę w powszechnym poborze, niebędącym niczym innym jak ponadnarodową realizacją jakobińskiego zawołania levée en masse, głoszącego konieczność uzbrojenia ludu, dzięki czemu postępowe pospolite ruszenie pokona reakcyjnych wrogów. Podczas wielkich wojennych zmagań w drugim dziesięcioleciu XX w. określono tym mianem mocarstwa centralne, w związku z czym ich klęska oraz Wielka Socjalistyczna Rewolucja Październikowa, kończąca misję dziejową „Żandarma Europy”, stworzyły warunki dla realizacji wilsonowskiej Zasady Samostanowienia Narodów, mających kopiować w tworzonych przez siebie państwach „jedynie słuszne” dogmaty Wielkich Zachodnich Demokracji. W Środkowo-Wschodniej Europie miało dojść do Przemiany, porównywalnej z chrystianizacją. Za- 
oceaniczny Wizjoner głosił konieczność zmiecenia monarchiczno-feudalnego zabobonu i zastąpienia go ludowo-egalitarnym porządkiem, uznanym w profetycznym zapale za optymalny dla wszystkich.

Co prawda po I wojnie światowej nie udało się w zupełności „uprogresywnić" centralno-orientalnych połaci Starego Kontynentu, ale po 1945 r. Wielki Projekt doczekał się realizacji, bowiem obszary te znalazły się w radzieckiej strefie wpływów, co było wystarczającą gwarancją dokończenia dzieła demokratyzacji stosunków ekonomiczno-społeczno-politycznych. Wprawdzie po podgrzaniu atmosfery politycznej przez zimną wojnę na Zachodzie odnoszono się krytycznie do niektórych błędów i wypaczeń, jakie dostrzeżono w „demoludach”, ale nie zanegowano podstawowego założenia ideologicznego, stanowiącego ich fundament, a mianowicie wyższości ludowładztwa nad konkurencyjnymi propozycjami ustrojowymi. Spór między Waszyngtonem a Moskwą był kłótnią w rodzinie, co wybitnie ułatwiło po pierestrojkowej desowietyzacji zorganizowanie okrągłych stołów i aksamitnych rewolucji, dzięki którym transformacje ustrojowe w postsatelickich państwach rozkładającego się Związku Radzieckiego przebiegły wyjątkowo gładko, gdyż nie zaistniała potrzeba wymiany fundamentów przemalowanych gmachów państwowych.

Co bardziej złośliwi mogliby głosić, że w dalszym ciągu są to baraki, tyle że Dawny Obóz gdzieś się zapodział, w związku z czym trzeba było rozpaczliwie szukać nowego schronienia, co zakończyło się sukcesem w postaci szczęśliwego pozbycia się przejściowej niezawisłości $\mathrm{w}$ upragnionych objęciach Eurounii. W końcu przyzwyczajenie jest drugą naturą, o czym zdają się wiedzieć wszystkie rozsądne siły polityczne makroregionu, ad nauseam wygłaszając oświadczenia o konieczności nieprzerwanej i pogłębionej integracji, spełniającej wielowiekowe marzenia wszystkich Europejczyków, genetycznie skłonnych do wspólnego radosnego bytowania, zwycięsko przezwyciężającego ponure demony faszyzmu, rasizmu, nacjonalizmu, totalitaryzmu i innych ideowych dewiacji, które oficjalnie uznano za niezasługujące na miano postępowych.

Dlatego mają one być zwalczane także, a raczej nawet przede wszystkim, wtedy gdy ich miazmaty zatruwają dusze uwiedzionych wyborców. Mają oni dokonywać rozsądnych wyborów, głosując na stronnictwa szeroko rozumianego centrum, których programy coraz bardziej upodabniają się do siebie. 
Mamy zatem do czynienia z „rozsądnie samoograniczającą się demokracją”, w której rozmaite krajowe i europejskie gremia stoją czujnie na straży „powszechnie akceptowanych standardów”, zwalczając ugrupowania „nadmiernie skrajne", zagrażające Jedynie Słusznemu Ładowi, mającemu trwać per omnia saecula saeculorum.

III.

Widzimy, że Europa Środkowo-Wschodnia w 1919 r. wkroczyła na drogę demokratycznych przemian, które uległy przyspieszeniu i pogłębieniu po 1944 r., aby po 1989 r. wejść w fazę „dojrzałej stabilizacji”. Wyraża się ona w próbach mechanicznego kopiowania tych zewnętrznych wzorców, jakie na aktualnym etapie rozwoju narzucane są przez obce mocarstwa, uznawane przez duchowo zhołdowane elity za bezdyskusyjne wzorce.

Trend ten odróżnia w dość fundamentalny sposób klimat społeczno-polityczny tej części świata od tego, który panował w przeszłości, kiedy to inspirowane $\mathrm{z}$ zewnątrz zmiany dokonywały się wolniej i były w większym stopniu przepuszczane przez filtr miejscowych tradycji i potrzeb. Tak było choćby z parlamentaryzmem, który do końca istnienia I Rzeczypospolitej nie przybrał typowej dla feudalnej Europy trójizbowej postaci. Było to związane ze zwiększaniem się przewagi wsi nad miastem - przeciwnie niż na Zachodzie, gdzie zurbanizowana burżuazja nieustannie rosła w siłę, niezależnie od tego, że trzecia izba zgromadzeń stanowych, którą miała do dyspozycji, zwiędła wraz ze średniowiecznym parlamentaryzmem w cieniu monarszego absolutyzmu, który wspierał się na mieszczanach $\mathrm{w}$ procesie osłabiania arystokracji. W federacji polsko-litewskiej, jak również na Węgrzech, miejska plutokracja była jednak zbyt słaba, aby dojrzewać do odgrywania samodzielnej roli politycznej, w czym przeszkadzał jej „sojusz dobrze urodzonych” magnatów i drobniejszych szlachciców, konstytuujących naród polityczny. W okcydentalnej optyce zadziwiającym zjawiskiem były wielotysięczne zgromadzenia konnych panów, zbierających się na wielodniowe zjazdy na świeżym powietrzu pod Warszawą lub nad Dunajem po to, by wybrać króla lub dokonać nowelizacji konstytucji, podczas gdy w zachodnioeuropejskich monarchiach już dawno prze- 
niesiono życie polityczne do dusznych sal w miastach, w których usadowiły się królewskie dwory.

W okcydentalnej Europie przejęły się one w XIX w. duchem konstytucjonalizmu lub uległy likwidacji wraz z republikanizacją państwowości. Zastanawiające jest, że ominęła ona Niderlandy oraz Skandynawię, a zatem niemocarstwowe państwowości, które do dzisiaj nie uległy republikańskiej modzie. Przeciwnie w Europie Środkowo-Wschodniej, która w XX stuleciu uległa totalnej republikanizacji, co wypada uznać za wierne naśladowanie wzorca amerykańsko-francusko-radzieckiego, z upodobaniem przyjmowanego w wybijających się na niepodległość państwach Zachodniej Półkuli, Afryki, Oceanii i Azji, elity których pragną uniknąć posądzeń o „wleczenie się w ogonie światowych przemian”. Ten sam mechanizm psychologiczno-polityczny funkcjonuje w centralno-orientalnej Europie z jej przywódcami żywiącymi głębokie przekonanie co do tego, że zamieszkują drugorzędną część kontynentu, niebędącą w stanie wytworzyć w sferze ideowo-politycznej czegoś oryginalnego, mogącego zainteresować resztę świata.

Ponieważ syndrom ten zdaje się nabierać coraz bardziej globalnego charakteru, co na wschód od obalonego Muru widać po 1989 r. z całą wyrazistością, obserwujemy proces ogólnoświatowej standaryzacji form ustrojowych, wyrażający się w zanikaniu państwowości przyciągających uwagę swoją oryginalnością. Onegdaj było dla nich więcej miejsca $\mathrm{z}$ powodu dosyć samodzielnego, w sporym stopniu niezależnego od reszty ludzkości, istnienia rozległych kręgów cywilizacyjnych, oddziaływania których osłabiały się wraz $\mathrm{z}$ oddalaniem się od centrum, co skutkowało powstawaniem na obrzeżach przekształconych postaci kanonicznych wzorców społeczno-ustrojowych. W tych buforowych czy też przechodnich, podlegających zróżnicowanym wpływom, państwowościach kształtowały się dosyć spontanicznie rozwiązania, wzbudzające wciąż zainteresowanie z powodu swojej oryginalności, po której zasadniczo pozostały zazwyczaj jedynie wspomnienia, przesłonięte coraz bardziej jednolitymi modelami realizowanymi w miarę zbliżania się do współczesności.

Potwierdzenie tej hipotezy o zmniejszającej się różnorodności w zakresie odmian politycznej organizacji społeczeństwa na szczeblu państwowym odnajdziemy, gdy spojrzymy na polityczną mapę interesującej nas części Europy sprzed 400 lat. Zobaczymy unię personalną Królestwa Polskiego z Wielkim 
Księstwem Litewskim, wciąż zachowującym sporą odrębność instytucjonalną i zwyczajową, powodującą, że byłoby ono monarchią w sporym stopniu wciąż patrymonialną, gdyby nie to, że władcy zazwyczaj przebywali w Krakowie, co stwarzało korzystne warunki dla rozrastania się potęgi kresowych królewiąt, nadając ustrojowi Wielkiej Litwy wyraźny rys arystokratyczny. Ci, którym on się nie podobał, uciekali nad Dniepr, gdzie organizowała się kozaczyzna, stanowiąca najbliższy „włáciwej Europy” przykład militokracji, typowego dla azjatyckich stepów zrzeszenia politycznego, konstytuowanego przez różnoplemiennych wojowników pozbawionych psychicznej potrzeby podlegania „wyposażonemu we wszelkie szykany” monarsze, którego z powodzeniem zastępował im obieralny hetman, będący przede wszystkim wodzem „siczowego bractwa”. Hetmanat wypada klasyfikować jako raczej republikańską niż monarchiczną formę państwa, przypominającą co nieco państwowości tworzone nad Morzem Śródziemnym i nad Bałtykiem przez rycerskie zakony.

W XVI w. jedno z nich istniało wciąż w Inflantach, gdzie gospodarzyli Kawalerowie Mieczowi, którym wbrew oczekiwaniom udało się dłużej utrzymać niezależne polityczne bytowanie niż Krzyżakom, ale w drugiej dekadzie XVI stulecia ci ostatni jeszcze jako zakonnicy władali nad wschodnimi Prusami, zanim ulegli pokusie protestantyzacji i sekularyzacji. Po czterdziestu latach ich szlakiem podążyli uzbrojeni zakonnicy z Inflant, zmniejszając potencjał ustrojowej różnorodności w tej części Europy.

W tym okresie był on współtworzony przez osmańską monokrację, posuwającą się w górę Dunaju w kierunku Budy i Wiednia. Godne uwagi jest to, że Wysoka Porta zasadniczo nie była monarchią, choć często jest traktowana właśnie w ten sposób. Trzeba jednak zdawać sobie sprawę z tego, że w islamskiej doktrynie politycznej nie występuje monarchizm w wyrazistej, porównywalnej do tej, z jaką mamy do czynienia w europejskich konstrukcjach, postaci. Muzułmanie konsekwentnie akcentują pierwszorzędne znaczenie ummy, czyli wspólnoty wiernych. Są oni równi względem Boga, co sprawia, że nikt spośród ludzi nie może uzyskać statusu Suwerena, zarezerwowanego dla Najwyższego. Powoduje to, że panujący, niezależnie od zakresu władzy, jaki skupia w swych rękach, nie ma szans na osiągnięcie takiego statusu prawno-państwowego, jaki jest udziałem chrześcijańskich cesarzy czy królów. Ci ostatni są namaszczani, co sprawia, że otacza ich sakralna aura, 
wyrażająca szczególny ontologiczny status, zdecydowanie różnicujący pomazańców od poddanych. Niczego podobnego nie odnajdziemy u muzułmanów, preferujących oddolną, ludową legitymizację władzy. Uczeni w Piśmie przekonują, że kalifowie czy sułtanowie zawsze byli wybierani, nawet jeżeli elekcja przybierała postać obioru przez padyszacha jednego spośród swoich licznych potomków.

Jeżeli weźmiemy pod uwagę, że zachodni cesarze też byli wybierani, podobnie jak polscy królowie i zaporoscy hetmani, a mistrzowie nadbałtyckich rycerskich zakonów bynajmniej nie mieli szans na przekazanie stanowiska swoim legalnym potomkom, to zauważymy, że elekcyjność, traktowana zazwyczaj jako conditio sine qua non ludowładztwa, jest silnie obecna w politycznej tradycji Środkowo-Wschodniej Europy, tym bardziej jeśli będziemy pamiętać o obieraniu posłów zasiadających po elekcji w Sejmie. Dynastyczność znacznie silniej występowała na Wołoszczyźnie i w Mołdawii, gdzie władali hospodarowie, których można potraktować jako odpowiedników książąt. Pomimo zwasalizowania przez Turcję możemy uznać te państwa za specyficzne monarchie, w których syntetyzowano bizantyjskie i islamskie wzorce ustrojowe. Potwierdzeniem tej hipotezy jest dokonane w XIX w. połączenie „naddunajskich księstw” w Królestwo Rumunii, w którym republikanizacja dokonała się po II wojnie światowej, a zatem później niż w innych częściach Makroregionu.

\section{IV.}

Zauważamy, że tradycja demokratyczna w Europie Środkowo-Wschodniej jest zakorzeniona w trzech wielkich denonimancjach wyznaniowych, wchodzących z sobą w kontakt w tej części świata. Mamy katolicyzm, współtworzący fascynującą szlachecką demokrację w Polsce, islam uparcie trwający przy ideale egalitarnego kalifatu z wybieralnym przywódcą i prawosławie, na bazie którego powstał fenomen siczowego kozackiego Hetmanatu. Można sformułować hipotezę, że wpływy tych trzech dużych wyznań, przynajmniej w takiej ich postaci, jaka istniała między Bałtykiem, Adriatykiem i Morzem Czarnym, przyczyniały się do utrzymywania się w świadomości i podświadomości zarówno rządzących elit, jak i szerokich mas, przekonania o nie- 
możności fundamentalnego porzucenia ludowładztwa, traktowanego jako generalnie słuszna koncepcja. Pogląd ten w oficjalnej postaci przejawi się po wkroczeniu Armii Czerwonej do zlewisk Wisły, Odry, Łaby i Dunaju, co skutkowało zainstalowaniem na tych obszarach reżimów określanych zastanawiającym mianem demokracji ludowych.

Abstrahując od ich ustrojowej praktyki, która okazała się średnim wyzwaniem dla okcydentalnych burżuazyjnych demokracji, skoro tym drugim udało się jakoś przetrzymać rywalizację, warto zastanowić się nad trafnością tej zbitki semantycznej, współcześnie przeważnie traktowanej jako oksymoron, choć przecież w Miłościwie Nam Panującej rodzimej Konstytucji „demokratycznego państwa prawnego" Lud nie występuje, skutecznie wyparty przez Naród, z czego wypadałoby wyciągnąć wniosek, że mamy do czynienia z narodową demokracją „nieludową”. W Polsce i innych państwach naszej części Europy nastąpiło „otwarcie na Zachód”, skutkujące między innymi kopiowaniem tamtejszych rozwiązań doktrynalnych, odzwierciedlających w wielu przypadkach „ducha 1789 r.”, kiedy to zdominowany przez burżuazję stan trzeci „stał się wszystkim”, czyli narodem. W Europie Środkowo-Wschodniej natomiast uzyskiwanie przez wzbogaconą mieszczańską elitę statusu suwerennego podmiotu władzy nie skutkowało w warunkach imperialnych państw wielonarodowych formalną emancypacją podległych centralnej władzy „niestołecznych” ludów. Ich doktrynalnie uświadomieni synowie tłumaczyli współplemieńcom, że bynajmniej nie wchodzą w skład panującego narodu politycznego, nabierającego coraz bardziej etnicznych cech wraz z postępami demokratyzacji, zmierzającej nieuchronnie do rozkładu imperiów, rozsadzanych przez narodowych demokratów, wzywających do emancypacji wciąż uciśnionych ludów.

Oficjalne ich powiązanie $z$ demokracją po II wojnie światowej wyrażało odcięcie się od „niesłusznych praktyk” przeszłości. „Oddanie demokracji ludowi” miało demonstrować jakościową różnicę między formalną demokracją na zachód od Żelaznej Kurtyny a jej głęboko bardziej zmaterializowaną odmianą w radzieckiej strefie wpływów, gdzie, jak głoszono, wszechstronnа уравниловка stwarzała dogodne warunki dla budowy komunistycznego społeczeństwa przyszłości, którego warunkiem sine qua non było urzeczywistnienie się marksistowsko-leninowskiej teorii obumierania państwa. Jednakże w powojennej fazie marszu ku komunizmowi państwa wciąż istniały, 
również te zaprzyjaźnione, charakteryzujące się tym, że były „socjalistyczne w treści i narodowe w formie". W wymiarze prawno-politycznym formuła ta była wyrażona przez ludową demokrację, gdzie lud przedstawia sobą czynnik socjalistyczny, a demokracja narodowy.

Lud kojarzony jest przede wszystkim z prowincjonalnym gminem, który nareszcie „wkroczył do śródmieścia”, przynosząc na obłoconych buciorach wspólnotowość, przechowaną w prawosławnej, muzułmańskiej czy katolickiej tradycji, będącą w sojuszu ze słowiańskim ideałem соборности, genetyczną germańską plemiennością, rumuńską skłonnością do zbiorowych wzruszeń i węgierską tęsknotą za zjednoczoną we wspólnym marszu stepową ordą. Twierdzono, że dzięki wyjściu naprzeciw odwiecznym tęsknotom uciśnionych mas narodowe państwa owładnięte teoretycznie przez lud demonstrowały „twórcze rozwinięcie demokratycznego ideału, zastygłego w burżuazyjnym parlamentaryzmie, który ewidentnie wyczerpał już wszelkie kreatywne możliwości”. Zagubiły się one w gąszczu partyjnych intryg, odzwierciedlających sprzeczne interesy różnych segmentów klasowo spolaryzowanego społeczeństwa. Owe antagonizmy uzyskały nową postać po zwycięstwie rewolucji socjalistycznej, skutkującej opanowaniem dźwigni władzy przez uświadomioną awangardę sprzymierzonej z postępowym chłopstwem klasy robotniczej. Lansowanie zasady jedności władzy państwowej uwidoczniało dążenie do dialektycznego odzyskania zmitologizowanej przedpaństwowej pierwotnej wspólnotowości, przetwarzanej w ten sposób, aby odpowiadała potrzebom nowych czasów.

Ten staro-nowy paradygmat politycznej organizacji społeczeństwa próbował odpowiedzieć na wątpliwości żywione przez wielkiego Proroka Nowożytnej Demokracji, za jakiego wypada uznać Jana Jakuba Rousseau, głoszącego wszem i wobec, że „demokracja jest ustrojem dla aniołów”, z czego płynie wniosek, że niedoskonały rodzaj ludzki nie za bardzo jest w stanie aplikować ludowładztwo w szerszym niż szwajcarskie kantony wymiarze, gdzie zresztą stanowi ono przykrywkę dla panowania lokalnych plutokratów. Zniesienie feudalizmu i kapitalizmu pozbawi szwajcarskich czy innych wyzyskiwaczy dotychczasowych możliwości, zamiast których wszyscy będą mogli sprawiedliwie korzystać z rozległych perspektyw, otwierających się w społeczeństwie bezklasowym. W procesie jego tworzenia ludy Europy Środkowo-Wschodniej miały być pasem transmisyjnym, za pomocą jakie- 
go wykuwany w ZSRR eurazjatycki socjalizm będzie przenoszony na spętany przez reakcyjne ideologie Zachód. Przychylne traktowanie tego eksperymentu przez całe zastępy zachodnich intelektualistów świadczy o tym, że istniało i zapewne $\mathrm{w}$ dalszym ciągu istnieje zainteresowanie modelem, który stanowiłby alternatywę wobec monarchicznej, względnie republikańskiej, parlamentokracji, skutkującej alienacją rządzących elit, słusznie oskarżanych o wypaczanie woli elektoratu, potrzebnego przede wszystkim dla legitymizowania sprawowania na co dzień władzy przez nielicznych.

\section{V.}

Zimnowojenna klęska Związku Radzieckiego spowodowała, że, przynajmniej w europejskim wymiarze, koncepcja syntetyzowania etnicznej państwowości z unifikującym ideologicznie władzę państwową ludowładztwem spoczęła „na śmietniku historii”, co oznacza, że dokonała się na obszarze fundamentów ustrojowych zachodnia rekonkwista wschodnich obszarów, przejściowo podążających własną prawno-polityczną drogą. Powtórzył się precedens chrystianizacji, która oznaczała wszak narzucenie „niewinnym, lubiącym sielanki Słowianom” obcego im do tej pory pojmowania świata i kosmosu, narzucanego per fas et nefas przez rezygnujących $\mathrm{z}$ własnego modelu władców. Co prawda, w przypadku demokracji ludowych nie zaszkodzi przypomnieć, że zasadniczo zostały one narzucone przez zwycięską Armię Czerwoną, tym niemniej upływ czasu spowodował, że doszło do częściowego przynajmniej zasiedzenia, zacierającego nieprawidłowości towarzyszące wprowadzaniu nowego ustroju.

Istnieją przesłanki upoważniające do potraktowania postawy partyjno-państwowych kierownictw, zachęcanych pod koniec lat osiemdziesiątych przez Moskwę do zasadniczej zmiany kursu jako zdrady elit, porzucających niekapitalistyczną drogę rozwoju i niekonfrontacyjną demokrację na rzecz obcego paradygmatu niezależnie od aprobaty szerokich mas, którym nigdzie nie dano zinstytucjonalizowanej możliwości dokonania wyboru między różnymi modelami ludowładztwa, a tym bardziej pomiędzy demokracją a jej alternatywami. W każdym razie niezwykle szybkie przestawienie się z jednej opcji na drugą, dotąd wyklinaną jako szpetną i heretycką, świadczy 
o tym, że kręgi opiniotwórcze Europy Środkowo-Wschodniej konsekwentnie podtrzymują pogląd o racjonalności implantowania zewnętrznych rozwiązań, żywiąc głęboko zakorzenione przekonanie o własnej niezdolności do samodzielnego wykreowania rozwiązań przydatnych zarówno dla siebie, jak i dla innych.

Trudno zatem się dziwić, że rozmontowanie porządku jałtańskiego doprowadziło do odkurzenia systemu stworzonego po $1918 \mathrm{r}$. w Wersalu i innych podparyskich miejscowościach, gdzie zachodnie Wielkie Demokracje demonarchizowały oraz dzieliły Środkowo-Wschodnią Europę „według racjonalnych, narodowych kryteriów”. Runięcie Muru skutkowało reunifikacją Niemiec oraz podziałem Związku Radzieckiego i Czechosłowacji na niezależne państwa narodowe konstytuowane przez części byłych federacji. Dzięki temu daje się obronić teza o pogłębieniu procesu realizacji zasady samostanowienia narodów, choć trzeba pamiętać, że konsekwentna realizacja tego ideału doprowadzałaby do zlikwidowania mniejszości narodowych, mających wszak do odegrania istotną rolę, skoro demokracja ma być „panowaniem większości z poszanowaniem praw mniejszości”. Ujęcie to skłania do uznania, że unifikacja etniczna ludności państwa stanowi zachętę dla uproszczenia systemu politycznego poprzez delegalizację opozycji, do czego zapewne kiedyś znowu dojdzie. Póki co jednak w państwach interesującego nas subkontynentu grzecznie odrabia się lekcję jedynie słusznego na aktualnym etapie rozwoju spolaryzowanego demoliberalizmu, co nie jest trudno zinterpretować jako „zwijanie się” historii, skoro zamiast zmierzać do postsocjalistycznego komunizmu, cofamy się, przynajmniej oficjalnie, do przerabianej już gospodarki rynkowej wraz z odpowiednią dla niej podobno nadbudową $\mathrm{w}$ postaci postfeudalnego parlamentaryzmu z coraz bardziej upodabniającymi się do siebie stronnictwami Głównego Nurtu. Ich przywódcy coraz niechętniej odwołują się do chrześcijańskich haseł, z upodobaniem zastępując je sloganami o demokratycznej, zjednoczonej Europie, bohatersko przezwyciężającej przejściowe trudności. Przy odrobinie chęci bez specjalnego wysiłku dostrzeżemy w tej narracji tęsknotę za powrotem do średniowiecza, kiedy to jeszcze „złowieszcze nacjonalizmy nie rozrywały boleśnie ciała Europy”. Upowszechnianie tej narracji oznacza wzrost krytycyzmu względem kilkuwiekowej Zachodniej Drogi Rozwoju, co może skutkować tym, że za jakiś czas urzędowi historycy ogłoszą, że jej narzucanie lu- 
dom środkowo-okcydentalnej Europy było głęboko niesłuszne, podobnie jak kolonizacja innych kontynentów. Wówczas okaże się, że ludowe demokracje, pańszczyzna, niezreformowane chrześcijaństwo, wiejskość, pasterstwo, szlachetczyzna, rozrzutna gościnność, silne związki rodzinne oraz inne peryferyjne fenomeny są niezwykle cenne, ponieważ stanowią istotny fragment Dorobku Ludzkości, przejawiającego się według niektórych w sposób najbardziej fascynujący na obrzeżach. W takiej sytuacji przydałoby się umownie odbudować Mur w celu ochrony „miejscowej ludności, fauny i flory” oraz intensywnie zachęcać do przywracania przygłuszonej Tradycji z ewentualnym jej uzupełnianiem elementami jeszcze bardziej swojskimi od autentycznych w celu uatrakcyjnienia. Dzięki przekuciu tego, co traktuje się przeważnie jako słabości, w powód do chwały, Europa Środkowo-Wschodnia uzyska, miejmy nadzieję, taki paradygmat cywilizacyjno-polityczny, który jej mieszkańcy będą mogli z dumą obnosić, a z czasem eksportować. W końcu skoro udało się to anglosaskiej Ameryce, gdzie udawały się „ostatnie wyrzutki społeczne, bezczelni chuligani wymiatani ze wstrętem z dobrej Europy", to każdemu może się powieść w tego typu przedsięwzięciu.

Artur Ławniczak Uniwersytet Wrocławski 